\title{
Peroxisome biogenesis in mammalian cells
}

\section{Yukio Fujiki *, Kanji Okumoto, Satoru Mukai, Masanori Honsho and Shigehiko Tamura}

Department of Biology, Faculty of Sciences, Kyushu University Graduate School, Fukuoka, Japan

\section{Edited by:}

Vladimir I. Titorenko, Concordia

University, Canada

Reviewed by:

Yasuyoshi Sakai, Kyoto University, Japan

Vladimir I. Titorenko, Concordia

University, Canada

*Correspondence:

Yukio Fujiki, Department of Biology, Faculty of Sciences, Kyushu

University Graduate School, 6-10-1

Hakozaki, Higashi-ku, Fukuoka

812-8581, Japan

e-mail: yfujiki@kyudai.jp
To investigate peroxisome assembly and human peroxisome biogenesis disorders (PBDs) such as Zellweger syndrome, thirteen different complementation groups (CGs) of Chinese hamster ovary $(\mathrm{CHO})$ cell mutants defective in peroxisome biogenesis have been isolated and established as a model research system. Successful gene-cloning studies by a forward genetic approach utilized a rapid functional complementation assay of $\mathrm{CHO}$ cell mutants led to isolation of human peroxin (PEX) genes. Search for pathogenic genes responsible for PBDs of all 14 CGs is now completed together with the homology search by screening the human expressed sequence tag database using yeast $P E X$ genes. Peroxins are divided into three groups: (1) peroxins including Pex3p, Pex16p, and Pex19p, are responsible for peroxisome membrane biogenesis via classes I and II pathways; (2) peroxins that function in matrix protein import; (3) those such as three forms of Pex11p, Pex11p $\alpha$, Pex11p $\beta$, and Pex11py, are involved in peroxisome proliferation where DLP1, Mff, and Fis1 coordinately function. In membrane assembly, Pex19p forms complexes in the cytosol with newly synthesized PMPs including Pex16p and transports them to the receptor Pex3p, whereby peroxisomal membrane is formed (Class I pathway). Pex19p likewise forms a complex with newly made Pex3p and translocates it to the Pex3p receptor, Pex16p (Class II pathway). In matrix protein import, newly synthesized proteins harboring peroxisome targeting signal type 1 or 2 are recognized by Pex5p or Pex7p in the cytoplasm and are imported to peroxisomes via translocation machinery. In regard to peroxisome-cytoplasmic shuttling of Pex5p, Pex5p initially targets to an $800-k D a$ docking complex consisting of Pex $14 p$ and Pex $13 p$ and then translocates to a $500-k D a$ RING translocation complex. At the terminal step, Pex $1 p$ and Pex6p of the AAA family mediate the export of Pex5p, where Cys-ubiquitination of Pex $5 p$ is essential for the Pex5p exit.

Keywords: $\mathrm{CHO}$ cell mutants, genetic phenotype-complementation, import machinery, membrane assembly, pathogenic genes, peroxins, peroxisome targeting signals, Zellweger syndrome

\section{INTRODUCTION}

Molecular mechanisms of peroxisome biogenesis, including peroxisomal import of newly synthesized matrix and membrane proteins, have been one of the major foci in the peroxisome research. Studies at the molecular level on both peroxisome assembly and peroxisome biogenesis disorders (PBDs) rapidly progressed in the last three decades. Studies on cloning of genes, particularly including those of a very low-level expression, have benefited from so-called functional cloning of genes, mostly cDNAs in mammalian cases, by phenotype complementation assay using cell mutants defective of biological pathways. The identification and characterization of numerous essential genes, termed PEXs encoding peroxisome biogenesis factors termed peroxins, by means of the genetic phenotype-complementation of peroxisome assembly-defective cell mutants, named pex mutants impaired in PEX genes. Such mutants from Chinese hamster ovary (CHO) cells (Table 1; see below) (Fujiki, 1997, 2000), several yeast species including Saccharomyces cerevisiae (Erdmann

Abbreviations: CG, complementation group; CHO, Chinese hamster ovary; DLP1, dynamin-like protein 1; EST, expressed sequence tag; PBD, peroxisome biogenesis disorder; PTS, peroxisomal targeting signal; ZS, Zellweger syndrome. et al., 1989), Pichia pastoris (Gould et al., 1992; Liu et al., 1992), Hansenula polymorpha (Cregg et al., 1990), and Yarrowia lipolytica (Nuttley et al., 1993) (also see reviews Van Der Klei and Veenhuis, 1996; Kunau, 1998; Tabak et al., 1999; Subramani et al., 2000; Titorenko and Rachubinski, 2001; Lazarow, 2003), and plant Arabidopsis thaliana (Hayashi and Nishimura, 2006) have made invaluable contributions to the investigations of peroxisome biogenesis and protein trafficking in eukaryotes (Schatz and Dobberstein, 1996; Wickner and Schekman, 2005). We herein summarize mammalian model cell systems in studying biogenesis, physiology, and human disorders of peroxisomes.

\section{GENETIC APPROACHES TO STUDYING MAMMALIAN PEROXISOME BIOGENESIS}

Basically two mutually complementary approaches have been taken for isolation of PEX genes encoding peroxins, i.e., the genetic phenotype-complementation of peroxisome biogenesisdefective mutants of mammalian somatic cells such as $\mathrm{CHO}$ cells and a combination of the human ortholog isolation by homology search on the human expressed sequence tag (EST) database using yeast PEX genes and cells derived from the patients with PBDs of 14 different genotypes, i.e., complementation groups (CGs) 
(Table 1; see below) (Fujiki, 1997, 2000, 2003; Gould and Valle, 2000; Weller et al., 2003).

\section{MAMMALIAN CELL MUTANTS DEFICIENT OF PEROXISOME}

Genetic heterogeneity consisting of 14 CGs were identified in PBDs by cell-fusion CG analysis using fibroblast cell lines derived from PBD patients (Fujiki, 2000; Ghaedi et al., 2000a; Gould and Valle, 2000; Matsumoto et al., 2001), where CGs 4 and 7 were revealed to be the same CGs as CGs 6 and 5, respectively (Table 1). A new CG, CG15, of ZS was also identified (Shimozawa et al., 2004), hence indicative of totally 13 genotypes of PBDs. The primary defect for PBDs was revealed to be the impaired biogenesis of peroxisomes (Fujiki, 2000; Gould and Valle, 2000). With respect to somatic animal cell mutants, 12 CGs of peroxisomedeficient $\mathrm{CHO}$ cell mutants were isolated, including a mutant ZP114 of a CG distinct from human CGs (Figure 1; Table1). A PBD patient of the 14th CG, CG16, was recently identified with pathogenic gene PEX11 $\beta$ (Ebberink et al., 2012). Together, genetic heterogeneity comprising 15 CGs are currently identified in mammals including humans and CHO cells.

\section{PEROXISOME BIOGENESIS GENES}

\section{Genetic phenotype-complementation screening}

$P E X$ s were isolated by genetic phenotype complementation of peroxisome biogenesis-deficient mutants of mammalian somatic cells including CHO cells (Figure 1A) and of several yeast species including S. cerevisiae, P. pastoris, H. polymorpha, and Y. lipolytica (Distel et al., 1996; Subramani et al., 2000; Fujiki et al., 2006b). Two mutually distinct but complementary approaches have been taken to identify and clone mammalian PEX genes.

A direct cloning approach has been taken by means of genetic complementation with peroxin cDNA essential for assembly of

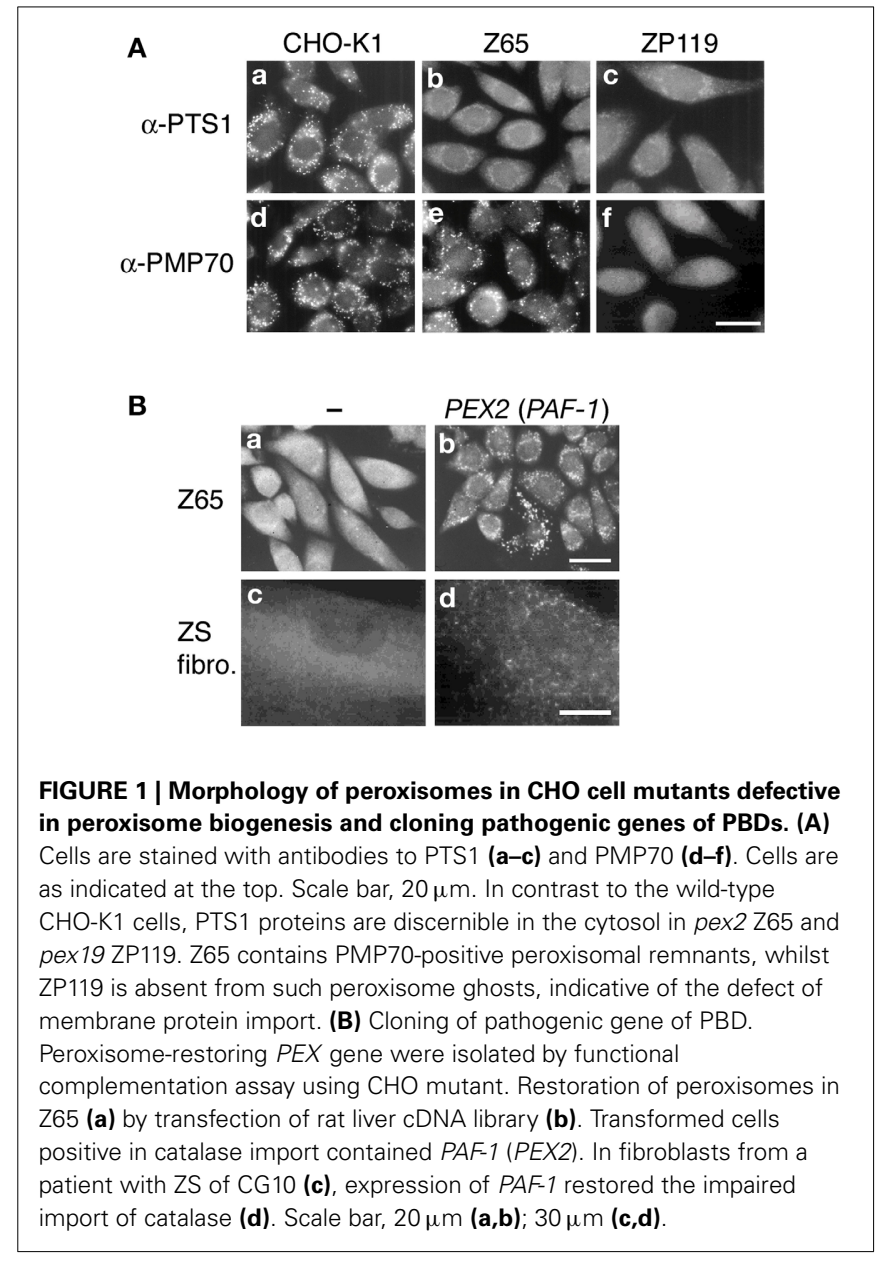

Table 1 | Complementation groups (CGs) and PEX genes of peroxisome deficiencies.

\begin{tabular}{|c|c|c|c|c|c|c|c|}
\hline Gene & \multicolumn{2}{|c|}{ CG } & Phenotype & CHO mutants & Peroxisome ghosts & \multicolumn{2}{|r|}{ Peroxin } \\
\hline PEX2 & 10 & $\mathrm{~F}$ & $\mathrm{ZS}, \mathrm{IRD} *$ & Z65 & + & 35 & PMP, RING \\
\hline PEX3 & 12 & G & ZS & ZPG208 & - & 42 & PMP, PMP-DP \\
\hline PEX5 & 2 & & ZS, NALD & ZP105*, ZP139 & + & 68 & PTS1 receptor, TPR family \\
\hline PEX10 & $7(5)$ & $\mathrm{B}$ & ZS, NALD & & + & 37 & PMP, RING \\
\hline$P E X 11 \beta$ & 16 & & ZS & & + & 28 & PMP \\
\hline PEX12 & 3 & & ZS, NALD, IRD & ZP109 & + & 40 & PMP, RING \\
\hline PEX13 & 13 & $\mathrm{H}$ & ZS, NALD* & ZP128 & + & 44 & PMP, PTS1-DP, SH3 \\
\hline PEX14 & 15 & K & ZS & ZP110 & + & 41 & PMP, PTS1-DP, PTS2-DP \\
\hline PEX26 & & & & ZP114 & + & & \\
\hline
\end{tabular}

*, Temperature-sensitive phenotype.

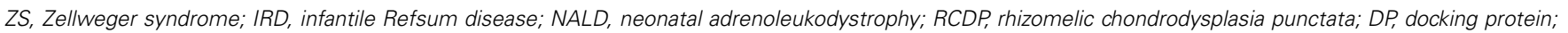
$P M P$, peroxisome membrane protein; TPR, tetratricopeptide repeat. 
peroxisomes in $\mathrm{CHO}$ cells. Establishment of an effective method, termed P12 (12-(1'-pyrene)dodecanoic acid)/ultraviolet selection method, made it feasible to isolate revertant (transfectant) cells showing a morphologically and biochemically normal peroxisome-phenotype, whereby PEX2 (formerly PAF-1) encoding the $35-\mathrm{kDa}$ membrane peroxin Pex2p with RING zinc-finger motif was cloned for the first time (Tsukamoto et al., 1991) (Figure 1B). Expression of PEX2 (called Zellweger gene) in fibroblasts from a ZS patient of CG10 (F) complemented the impaired peroxisome biogenesis (Shimozawa et al., 1992) (Figure 1B). Dysfunction of PEX2 caused by a homozygous nonsense point mutation at R119ter was shown for the first time to be responsible for ZS, a prototype of the PBDs (Shimozawa et al., 1992). A more practical approach, i.e., a transient expression assay, was also developed for further isolation of $P E X$ cDNAs including nine others, PEX1, PEX3, PEX5, PEX6, PEX12, PEX13, PEX14, PEX19, and PEX26 (Fujiki, 2003; Fujiki et al., 2006b) (Figure 2). These PEXs were shown to be the pathogenic genes involved in PBDs of nine CGs (Weller et al., 2003; Fujiki et al., 2006b; Fujiki, 2011) (Table 1).

\section{Expressed sequence tag homology search}

As an alternative method, the homology search by screening the human EST database using yeast PEX genes successfully led to isolation of human ortholog genes responsible for PBDs: PEX1, PEX3, PEX5, PEX6, PEX7, PEX10, PEX12, PEX13, and PEX16 (Weller et al., 2003; Fujiki et al., 2006b).

All of pathogenic genes responsible for PBDs of currently identified 13 CGs have been successfully cloned within about 10 years after the first isolation of the ZS gene, PEX2, by such extensive search using the mutually complementary methods.

\section{BIOGENESIS OF PEROXISOMES MEMBRANE BIOGENESIS}

Three mammalian peroxins, Pex3p, Pex16p, and Pex19p, were isolated by the functional phenotype-complementation assay on CHO cell mutants (Matsuzono et al., 1999; Ghaedi et al., 2000b) and the EST database search using yeast PEX genes (Kammerer et al., 1997, 1998; Honsho et al., 1998; South and Gould, 1999) and were shown to be exclusively required for membrane

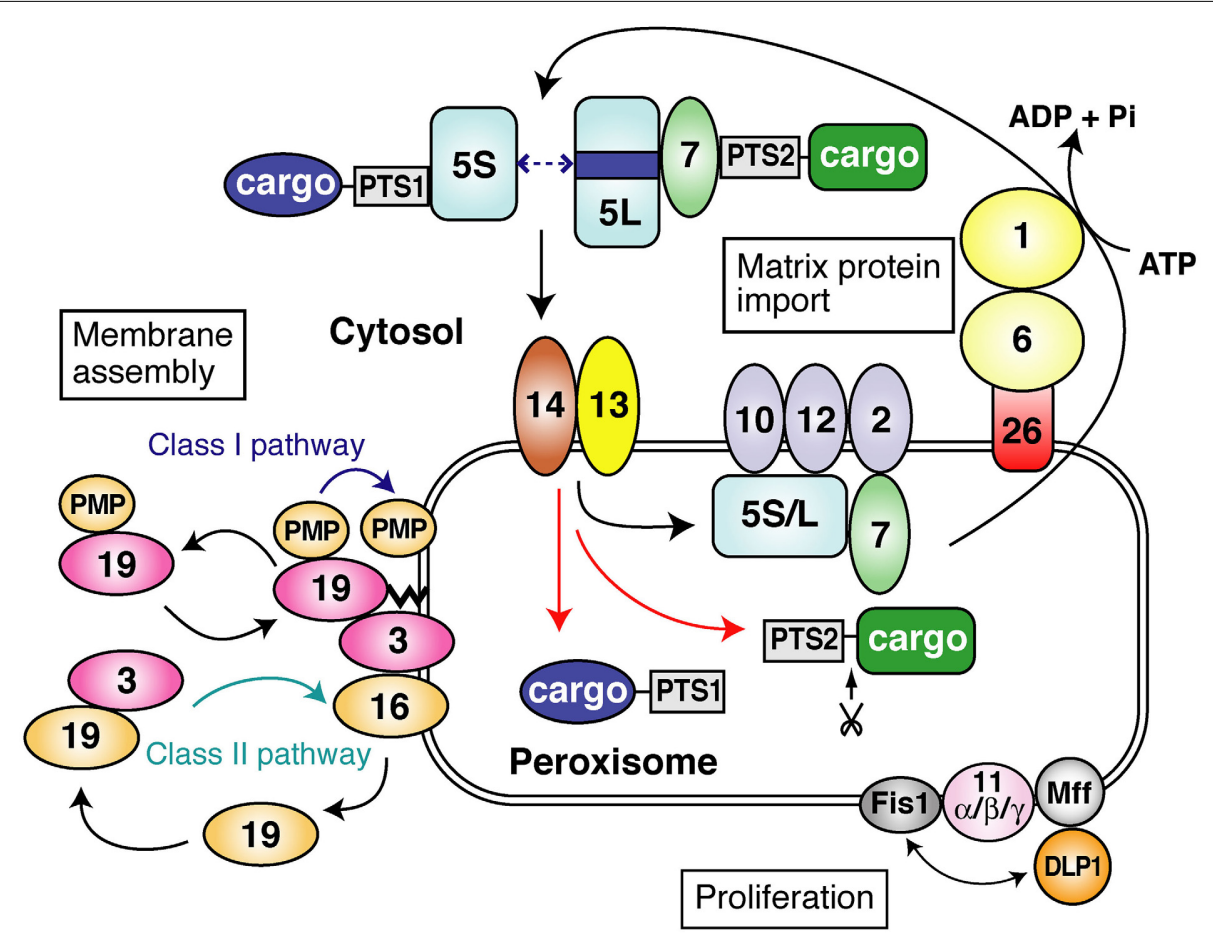

FIGURE 2 | A schematic view of peroxisome biogenesis in mammalian cells. The subcellular localization and molecular characteristics of peroxins are shown. Peroxins are classified into three groups: (1) peroxins that are required for matrix protein import; (2) those including Pex3p, Pex16p and Pex19p, responsible for peroxisome membrane assembly via classes I and II pathways (see in this figure); (3) those such as three forms of Pex11p, Pex11p $\alpha, P e x 11 p \beta$, and Pex11p $\gamma$, apparently involved in peroxisome proliferation where DLP1, Mff, and Fis1 coordinately function. PTS1 and PTS2 proteins are recognized by Pex $5 p$ and Pex7p, respectively, in the cytoplasm. Two isoforms, Pex $5 p S$ and Pex5pL, of Pex5p are identified in mammals. PTS1 proteins are transported by homo- and hetero-oligomers of Pex $5 \mathrm{pS}$ and Pex $5 \mathrm{pL}$ to peroxisomes, where Pex $14 p$ functions as a convergent, initial docking site of the "protein import machinery" translocon. Pex $5 \mathrm{pL}$ directly interacts with the PTS2 receptor, Pex7p, carrying its cargo PTS2 protein in the cytosol and translocates the Pex7p-PTS2 protein complex to Pex14p. PTS1 and PTS2 proteins are then released the inner surface and/or inside of peroxisomes, downstream Pex14p and upstream Pex13p. Pex5p and Pex7p subsequently translocate to other translocon components, named translocation complex comprising the RING peroxins, Pex $2 p$, Pex $10 p$, and Pex12p. Both Pex5p and Pex7p finally shuttle back to the cytosol. In regard to peroxisome-cytoplasmic shuttling of Pex $5 p$, Pex $5 p$ initially targets to an $800-k D a$ docking complex containing Pex $14 p$ and then translocates to a 500-kDa translocation complex comprising RING peroxins. At the terminal step of the protein import reaction, Pex $1 p$ and Pex6p of the AAA family catalyze the export of Pex5p, where Cys-ubiquitination of Pex5p is prerequisite to the Pex $5 p$ exit. 
assembly of peroxisomes. Mechanistic insights on membrane biogenesis are addressed here.

\section{Peroxins essential for membrane assembly of peroxisomes}

Of 13 peroxins of which mutations are responsible for PBDs, Pex3p, Pex16p, and Pex19p were identified as essential factors for PMP assembly in several species including humans (Baerends et al., 1996; Götte et al., 1998; Honsho et al., 1998; Matsuzono et al., 1999; South and Gould, 1999; Ghaedi et al., 2000a; Hettema et al., 2000; Sacksteder et al., 2000; South et al., 2000; Otzen et al., 2004) (Figure 1). Pex19p is a predominantly cytoplasmic protein that shows a broad PMP-binding specificity; Pex3p serves as the membrane-anchoring site for Pex19p-PMP complexes (Class I pathway); and Pex16p-a protein absent in most yeasts (Eitzen et al., 1997; South and Gould, 1999) functions as the receptor for Pex19p complexes with newly synthesized Pex3p (Matsuzaki and Fujiki, 2008) (Class II pathway) (Figures 2, 3). The function of Pex16p is not conserved between different species. In addition, under debate remains whether Pex19p has a chaperone-like role in the cytosol or at the peroxisome membrane and/or functions as a cycling import receptor for newly synthesized PMPs (Fujiki et al., 2006a).

\section{Gene defects of peroxins required for both membrane biogenesis and matrix protein import}

Impairment of Pex3p, Pex16p, and Pex19p, causes the most severe PBD, ZS, of three CGs, CG12 (G), CG9 (D), and CG14 (J), respectively (Weller et al., 2003; Fujiki et al., 2006b, 2012; Fujiki, 2011) (Table 1).

Pex19p. PEX19 encodes 33-kDa farnesylated protein harboring farnesylation CAAX box motif localized mostly in the cytosol and only partly anchored to peroxisomal membranes (Matsuzono et al., 1999). PEX19 expression complemented impaired peroxisome assembly in fibroblasts from a patient with CG14 (J) PBD. This patient was a homozygote for inactivating mutation: a onebase insertion, A764, in a codon for $\mathrm{Met}^{255}$, thereby resulting in a frameshift. Upon transfection of PEX19 into a CHO pex19 mutant ZP119 devoid of peroxisomal remnants called ghosts, most striking was formation of peroxisomal membranes, prior to the import of matrix proteins (Matsuzono et al., 1999; Sacksteder et al., 2000). This was the first demonstration of the membrane assembly process during peroxisome biogenesis, particularly differentiated from the soluble protein import.

Pex16p. Fibroblasts from a ZS patient of CG9 (D) are deficient in peroxisomal membrane remnants, as in PEX19-defective fibroblasts of CG14 (J). Expression of PEX16 encoding 336-amino-acid peroxisomal membrane protein restored peroxisomal membrane biogenesis and matrix protein import in CG9 (D) fibroblasts (Honsho et al., 1998; South and Gould, 1999), of which mutation was a homozygous nonsense mutation R176ter (Honsho et al., 1998). More recently, other mutations are identified: exon 10 skip (Shimozawa et al., 2002) and five novel homozygous mutations (Ebberink et al., 2010).

Pex3p. Mammalian PEX3 encodes 42-kDa integral membrane protein of peroxisomes (Ghaedi et al., 2000a,b). Upon expression

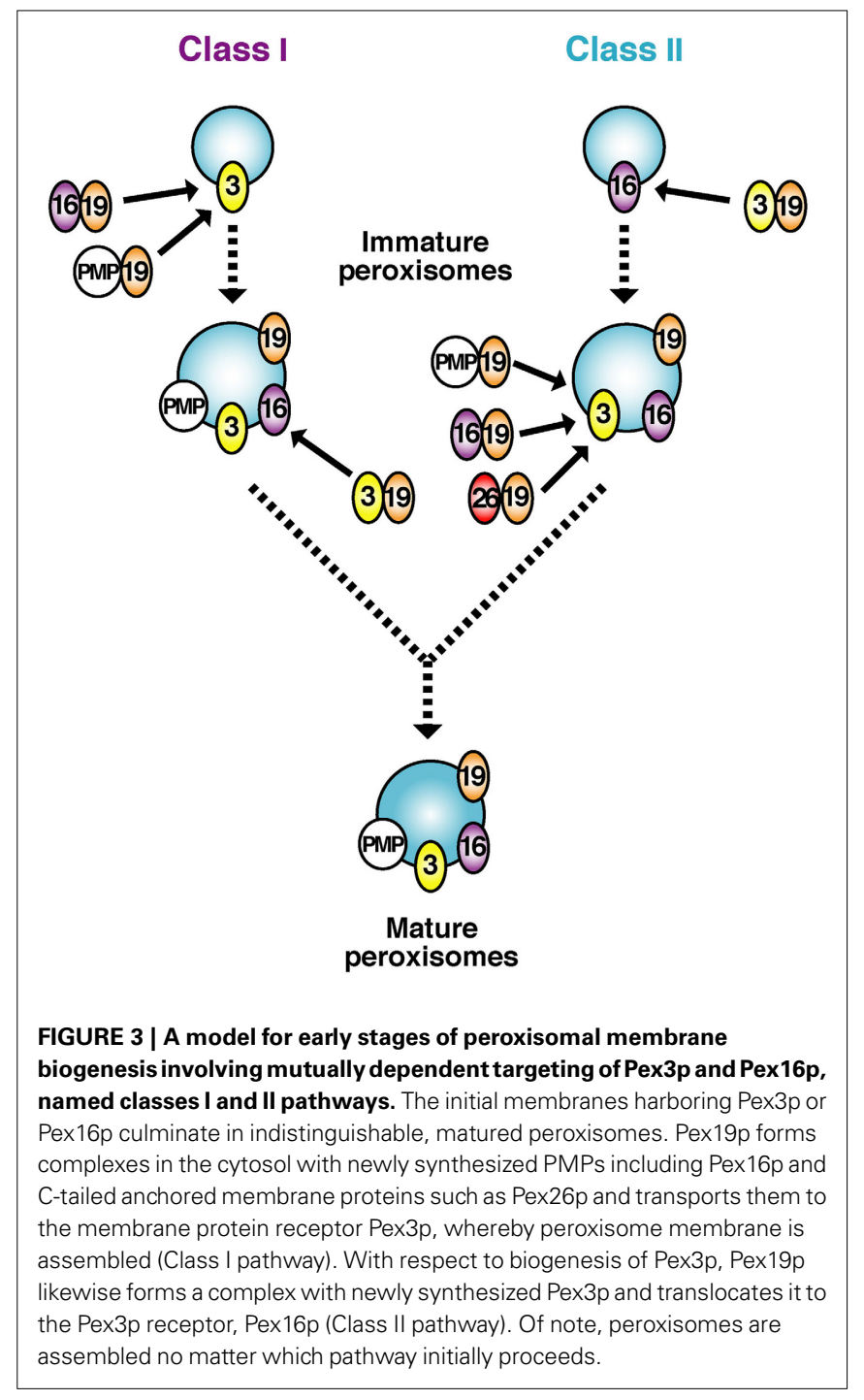

of PEX3 in a CHO pex3 mutant (Ghaedi et al., 2000b) and fibroblasts from three ZS patients of CG12 (G) (Ghaedi et al., 2000a), peroxisomal membrane vesicles were assembled prior to the import of soluble proteins (Ghaedi et al., 2000a; Muntau et al., 2000; Shimozawa et al., 2000; South et al., 2000; Fujiki et al., 2006a; Fujiki, 2011), as in pex19 and pex16 patientsderived cells (see above), likewise implying the temporally differentiated translocation of matrix proteins into peroxisomal membrane vesicles. Two types of mutations, exon 11 deletion and a single-nucleotide insertion in the codon for $\mathrm{Val}^{182}$ in exon 7, in PEX3 were identified in the ZS patients (Ghaedi et al., 2000a; Muntau et al., 2000; Shimozawa et al., 2000).

Taken together, Pex3p, Pex16p, and Pex19p are categorized as a peroxin exclusively required for the assembly of peroxisome membranes. They function as essential factors in the transport process of membrane proteins and membrane vesicle assembly in a concerted manner. Two distinct pathways were recently suggested for the import of PMPs: a Pex19p- and Pex3p-dependent 
class I pathway for PMP-import complex, except for Pex3p (Fang et al., 2004; Matsuzono et al., 2006) and a Pex19p- and Pex16pdependent class II pathway for Pex3p (Matsuzaki and Fujiki, 2008) (Figures 2, 3). It is noteworthy that C-tailed anchor-type peroxin Pex26p, the recruiter of Pex1p-Pex6p complex, is transported in a Pex19p-dependent (Halbach et al., 2006), class I pathway (Yagita et al., 2013), which is distinct from the GET3dependent topogenesis of yeast Pex15p, a functional ortholog of Pex26p (Schuldiner et al., 2008).

\section{Involvement of ER in peroxisome biogenesis}

In regard to involvement of the ER in peroxisome biogenesis, ER was postulated to provide the initial "seed" for recruiting other components required for peroxisome assembly (Kim et al., 2006; Ma et al., 2011; Tabak et al., 2013). Several groups suggested a different view of peroxisomal membrane biogenesis that peroxisomes are formed from ER upon induction of Pex3p (Hoepfner et al., 2005; Kragt et al., 2005; Kim et al., 2006), although the significance of such observations remains under debate. Recently, a study (Motley and Hettema, 2007) suggest that peroxisomes are generally formed by growth and division under normal conditions and that only under a condition where no peroxisome is present in a cell, they can be formed from the ER after the expression of the complementing PEX gene, whilst another study (Van Der Zand et al., 2010) proposes that all peroxisomal membrane proteins are transported via ER. Meanwhile, we demonstrated that Pex3p, the membrane receptor for Pex19p-complexes with PMPs including Pex16p, is directly targeted to peroxisomes in a Pex19p-Pex16p dependent class II pathway in mammalian cells such as CHO and human cell lines (Matsuzaki and Fujiki, 2008). Moreover, it is noteworthy that several peroxisomal membrane proteins might be transported to peroxisomes via ER (Lam et al., 2010; Agrawal et al., 2011; Yonekawa et al., 2011), likely implying a sort of semi-autonomous property of peroxisomes. At any event, the issue with respect to how peroxisome membrane is assembled is one of the important and of highly interesting problems to be tackled (Ma et al., 2011; Fujiki et al., 2012; Tabak et al., 2013).

\section{MATRIX PROTEIN IMPORT}

Ten peroxins including Pexlp, Pex2p, Pex5p, Pex6p, Pex7p, Pex10p, Pex12p, Pex13p, Pex14p, and Pex26p are involved in protein import into peroxisomal matrix (Figure 2) (Fujiki et al., 2006a).

\section{Peroxisome-cytoplasmic shuttling of import receptors}

PTS1 and PTS2 proteins are recognized by Pex5p and Pex7p, respectively, in the cytoplasm. In mammalian cells, PTS1 proteins are transported by homo- and hetero-oligomers of Pex5pS and Pex5pL to peroxisomes, where Pex14p functions as the initial site of an $800-\mathrm{kDa}$ "docking complex." Pex5pL translocates the Pex7p-PTS2 protein complex to Pex14p (Otera et al., 2002; Miyata and Fujiki, 2005). After releasing the cargoes, Pex5p and Pex7p translocate to a $500-\mathrm{kDa}$ "translocation complex" comprising the RING peroxins, Pex2p, Pex10p and Pex12p (Miyata and Fujiki, 2005). Both Pex5p and Pex7p finally translocate back to the cytosol (Dammai and Subramani, 2001; Gouveia et al., 2003; Nair et al., 2004; Miyata and Fujiki, 2005; Platta et al.,
2005; Miyata et al., 2009). At the terminal step of the protein import reaction, AAA peroxins, Pexlp and Pex6p, recruited to Pex26p (Pex15p in yeast) on peroxisomes catalyze the ATPdependent export of Pex5p (Miyata and Fujiki, 2005; Platta et al., 2005). Ubiquitination of Pex5p is prerequisite for the Pex5p exit (Carvalho et al., 2007; Williams et al., 2007; Okumoto et al., 2011).

Mono-ubiquitination of the conserved cysteine residue at position 11 in the $\mathrm{N}$-terminal region of mammalian Pex $5 p$ plays an essential role in the recycling, especially in the export step from peroxisomes to the cytosol (Grou et al., 2009; Okumoto et al., 2011; Miyata et al., 2012), as in yeast (Platta et al., 2009). A cytosolic factors, AWP1/ZFAND6 involved in the recycling of Pex5p is recently identified in mammals (Miyata et al., 2012); USP9X and Ubp15 are suggested as a potential deubiquitinase in mammals (Grou et al., 2012) and yeast (Debelyy et al., 2011), respectively. A distinct redox state may affect the recycling of Pex5p requiring Cys-ubiquitination, thereby leading as a possible cause to the phenotype of deficiency in protein import in PEX-defective cells.

\section{REDOX STATE OF NORMAL AND PEROXISOME-DEFICIENT CELLS}

In peroxisomes possessing a fatty acid $\beta$-oxidation system in wildtype $\mathrm{CHO}$ cells, the redox state within the peroxisomes is more reductive than that in the cytosol, despite the fact that reactive oxygen species are generated within the peroxisomes (Yano et al., 2010). Moreover, to our surprise, the redox state in the cytosol of pex cell mutants is more reductive than that of the wild-type CHO cells (Yano et al., 2010). Such distinct redox state may affect the recycling of Pex5p requiring Cys-ubiquitination, thereby leading as a possible cause to the phenotype of deficiency in protein import in PEX-defective cells including cell lines from patients with PBDs. A potential way to cure the PBD patients may be a screening for agents that moderate the abnormal cytosolic redox state in the pex cell lines including the cells with nonredox-sensitive mutations in PEXs. It is noteworthy that in $P$. pastoris PTS1-cargo release from Pex5p is achieved by a redox-regulated oligomer to dimer transition of Pex5 $p$ and aided by Pex8p (Ma et al., 2013). Interestingly, intraperoxisomal redox status is strongly influenced by environmental growth conditions (Ivashchenko et al., 2011).

\section{GENE DEFECTS OF PROTEINS FOR PEROXISOMAL MORPHOGENESIS}

Three isoforms of Pex11p family, Pex11p $\alpha$ (Abe et al., 1998; Li et al., 2002a), Pex11p $\beta$ (Abe and Fujiki, 1998; Schrader et al.,

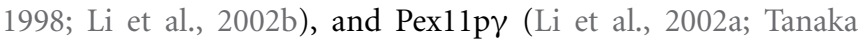
et al., 2003), are identified as factors involved in morphogenesis of peroxisomes in mammals (Kobayashi et al., 2007; Delille et al., 2010; Koch et al., 2010; Itoyama et al., 2013). In mammalian cells, dynamin-like protein 1 (DLP1) (Koch et al., 2003; Li and Gould, 2003; Tanaka et al., 2006; Waterham et al., 2007), fission 1 (Fis1) (Koch et al., 2005; Kobayashi et al., 2007), and mitochondrial fission factor (Mff) (Gandre-Babbe and Van Der Bliek, 2008; Otera et al., 2010; Koch and Brocard, 2012; Itoyama et al., 2013) are shown to be involved in the fission of peroxisomes.

In regard to peroxisomal dysmorphogenesis in humans, only two patients have been identified with a different defect in any 
of the proteins involved in the proliferation and division of peroxisomes. The first reported patient was a severely affected female patient, who died 1 month after birth and postmortally was found to have a dominant-negative heterozygous mutation in the DLP1 gene, which resulted in a severe fission defect of both peroxisomes and mitochondria (Waterham et al., 2007). More recently, the first patient with a defect of peroxisomal division due to a homozygous nonsense mutation in the PEX11 $\beta$ gene was reported as the 14 th CG (CG16) of PBDs (Ebberink et al., 2012) (Table 1).

\section{PERSPECTIVE}

Mammalian cell mutants of 15 CGs defective of peroxisome biogenesis have been identified, including PBD patients' fibroblasts and $\mathrm{CHO}$ mutant cell lines (Table 1). Pathogenic genes are now elucidated for all of PBD CGs. Biochemical functions of peroxins involved in the import of matrix proteins are better elucidated, whilst molecular mechanisms underlying the membrane assembly are less understood. Defects in peroxisomal morphogenesis have also been recently reported. Investigations using the cloned peroxins and pex mutants including $\mathrm{CHO}$ mutants and those from PBD patients will shed light on the mechanisms involved in biogenesis and morphogenesis of peroxisomes and pathogenesis of PBDs.

\section{ACKNOWLEDGMENTS}

We thank all of our colleagues of the Fujiki's laboratory who contributed to the work discussed in this review. We thank K. Shimizu for figure illustrations. This work was supported in part a CREST grant (to Yukio Fujiki) from the Science and Technology Agency of Japan, Grants-in-Aid for Scientific Research (19058011, 20370039, and 24247038, 25112518, 25116717, and 26116007 to Yukio Fujiki; 21770117, 24770130, and 26440032 to Kanji Okumoto; 23570236 and 26440102 to Masanori Honsho; 21570116 and 24570134 to Shigehiko Tamura), Global Center of Excellence (GCOE) Program, The Grants for Excellent Graduate Schools from the Ministry of Education, Culture, Sports, Science and Technology of Japan, and grants (to Yukio Fujiki) from Takeda Science Foundation and Japan Foundation for Applied Enzymology.

\section{REFERENCES}

Abe, I., and Fujiki, Y. (1998). cDNA cloning and characterization of a constitutively expressed isoform of the human peroxin Pex11p. Biochem. Biophys. Res. Commun. 252, 529-533. doi: 10.1006/bbrc.1998.9684

Abe, I., Okumoto, K., Tamura, S., and Fujiki, Y. (1998). Clofibrate-inducible, 28$\mathrm{kDa}$ peroxisomal integral membrane protein is encoded by PEX11. FEBS Lett. 431, 468-472. doi: 10.1016/S0014-5793(98)00815-1

Agrawal, G., Joshi, S., and Subramani, S. (2011). Cell-free sorting of peroxisomal membrane proteins from the endoplasmic reticulum. Proc. Natl. Acad. Sci. U.S.A. 108, 9113-9118. doi: 10.1073/pnas.1018749108

Baerends, R. J. S., Rasmussen, S. W., Hilbrands, R. E., Van Der Heide, M., Faber, K. N., Reuvekamp, P. T. W., et al. (1996). The Hansenula polymorpha PER9 gene encodes a peroxisomal membrane protein essential for peroxisome assembly and integrity. J. Biol. Chem. 271, 8887-8894. doi: 10.1074/jbc.271.15.8887

Carvalho, A. F., Pinto, M. P., Grou, C. P., Alencastre, I. S., Fransen, M., Sá-Miranda, C., et al. (2007). Ubiquitination of mammalian Pex5p, the peroxisomal import receptor. J. Biol. Chem. 282, 31267-31272. doi: 10.1074/jbc.M706325200

Cregg, J. M., Vankiel, I. J., Sulter, G. J., Veenhuis, M., and Harder, W. (1990). Peroxisome-deficient mutants of Hansenula polymorpha. Yeast 6, 87-97. doi: 10.1002/yea.320060202
Dammai, V., and Subramani, S. (2001). The human peroxisomal targeting signal receptor, Pex5p, is translocated into the peroxisomal matrix and recycled to the cytosol. Cell 105, 187-196. doi: 10.1016/S0092-8674(01) 00310-5

Debelyy, M. O., Platta, H. W., Saffian, D., Hensel, A., Thoms, S., Meyer, H. E., et al. (2011). Ubp15p, a ubiquitin hydrolase associated with the peroxisomal export machinery. J. Biol. Chem. 286, 28223-28234. doi: 10.1074/jbc.M111.238600

Delille, H. K., Agricola, B., Guimaraes, S. C., Borta, H., Lüers, G. H., Fransen, M., et al. (2010). Pex11p $\beta$-mediated growth and division of mammalian peroxisomes follows a maturation pathway. J. Cell Sci. 123, 2750-2762. doi: $10.1242 /$ jcs.062109

Distel, B., Erdmann, R., Gould, S. J., Blobel, G., Crane, D. I., Cregg, J. M., et al. (1996). A unified nomenclature for peroxisome biogenesis factors. J. Cell Biol. 135, 1-3. doi: 10.1083/jcb.135.1.1

Ebberink, M. S., Csanyi, B., Chong, W. K., Denis, S., Sharp, P., Mooijer, P., et al. (2010). Identification of an unusual variant peroxisome biogenesis disorder caused by mutations in the PEX16 gene. J. Med. Genet. 47, 608-615. doi: 10.1136/jmg.2009.074302

Ebberink, M. S., Koster, J., Visser, G., Van Spronsen, F., Stolte-Dijkstra, I., Smit, G. P. A., et al. (2012). A novel defect of peroxisome division due to a homozygous non-sense mutation in the PEX11 $\beta$ gene. J. Med. Genet. 49, 307-313. doi: 10.1136/jmedgenet-2012-100778

Eitzen, G. A., Szilard, R. K., and Rachubinski, R. A. (1997). Enlarged peroxisomes are present in oleic acid-grown Yarrowia lipolytica overexpressing the PEX16 gene encoding an intraperoxisomal peripheral membrane peroxin. J. Cell Biol. 137, 1265-1278. doi: 10.1083/jcb.137.6.1265

Erdmann, R., Veenhuis, M., Mertens, D., and Kunau, W.-H. (1989). Isolation of peroxisome-deficient mutants of Saccharomyces cerevisiae. Proc. Natl. Acad. Sci. U.S.A. 86, 5419-5423. doi: 10.1073/pnas.86.14.5419

Fang, Y., Morrell, J. C., Jones, J. M., and Gould, S. J. (2004). PEX3 functions as a PEX19 docking factor in the import of class I peroxisomal membrane proteins. J. Cell Biol. 164, 863-875. doi: 10.1083/jcb.200311131

Fujiki, Y. (1997). Molecular defects in genetic diseases of peroxisomes. Biochim. Biophys. Acta 1361, 235-250. doi: 10.1016/S0925-4439(97)00051-3

Fujiki, Y. (2000). Peroxisome biogenesis and peroxisome biogenesis disorders. FEBS Lett. 476, 42-46. doi: 10.1016/S0014-5793(00)01667-7

Fujiki, Y. (2003). "Peroxisome biogenesis disorders," in Nature Encyclopedia of the Human Genome, ed D. N. Cooper. (London: Nature Publishing Group), 541-547.

Fujiki, Y. (2011). “Peroxisome biogenesis disorders," in Encyclopedia of Life Sciences (Chichester: John Wiley \& Sons). doi: 10.1002/9780470015902.a0006109.pub2

Fujiki, Y., Matsuzono, Y., Matsuzaki, T., and Fransen, M. (2006a). Import of peroxisomal membrane proteins: the interplay of Pex3p- and Pex19pmediated interactions. Biochim. Biophys. Acta 1763, 1639-1646. doi: 10.1016/j.bbamcr.2006.09.030

Fujiki, Y., Okumoto, K., Kinoshita, N., and Ghaedi, K. (2006b). Lessons from peroxisome-deficient Chinese hamster ovary $(\mathrm{CHO})$ cell mutants. Biochim. Biophys. Acta 1763, 1374-1381. doi: 10.1016/j.bbamcr.2006.09.012

Fujiki, Y., Yagita, Y., and Matsuzaki, T. (2012). Peroxisome biogenesis disorders: molecular basis for impaired peroxisomal membrane assembly- In metabolic functions and biogenesis of peroxisomes in health and disease. Biochim. Biophys. Acta 1822, 1337-1342. doi: 10.1016/j.bbadis.2012.06.004

Gandre-Babbe, S., and Van Der Bliek, A. M. (2008). The novel tail-anchored membrane protein Mff controls mitochondrial and peroxisomal fission in mammalian cells. Mol. Biol. Cell. 19, 2402-2412. doi: 10.1091/mbc.E07-12-1287

Ghaedi, K., Honsho, M., Shimozawa, N., Suzuki, Y., Kondo, N., and Fujiki, Y. (2000a). PEX3 is the causal gene responsible for peroxisome membrane assembly-defective Zellweger syndrome of complementation group G. Am. J. Hum. Genet. 67, 976-981. doi: 10.1086/303086

Ghaedi, K., Tamura, S., Okumoto, K., Matsuzono, Y., and Fujiki, Y. (2000b). The peroxin Pex3p initiates membrane assembly in peroxisome biogenesis. Mol. Biol. Cell 11, 2085-2102. doi: 10.1091/mbc.11.6.2085

Götte, K., Girzalsky, W., Linkert, M., Baumgart, E., Kammerer, S., Kunau, W.-H., et al. (1998). Pex19p, a farnesylated protein essential for peroxisome biogenesis. Mol. Cell. Biol. 18, 616-628.

Gould, S. J., McCollum, D., Spong, A. P., Heyman, J. A., and Subramani, S. (1992). Development of the yeast Pichia pastoris as a model organism for a genetic and molecular analysis of peroxisome assembly. Yeast 8, 613-628. doi: 10.1002/yea.320080805 
Gould, S. J., and Valle, D. (2000). Peroxisome biogenesis disorders: genetics and cell biology. Trends Genet. 16, 340-345. doi: 10.1016/S0168-9525(00)02056-4

Gouveia, A. M., Guimaraes, C. P., Oliveira, M. E., Reguenga, C., Sa-Miranda, C., and Azevedo, J. E. (2003). Characterization of the peroxisomal cycling receptor, Pex5p, using a cell-free in vitro import system. J. Biol. Chem. 278, 226-232. doi: 10.1074/jbc.M209498200

Grou, C. P., Carvalho, A. F., Pinto, M. P., Huybrechts, S. J., Sá-Miranda, C., et al. (2009). Properties of the ubiquitin-Pex5p thiol ester conjugate. J. Biol. Chem. 284, 10504-10513. doi: 10.1074/jbc.M808978200

Grou, C. P., Francisco, T., Rodrigues, T. A., Freitas, M. O., Pinto, M. P., Carvalho, A. F., et al. (2012). Identification of ubiquitin-specific protease 9X (USP9X) as a deubiquitinase acting on ubiquitin-peroxin 5 (PEX5) thioester conjugate. J. Biol. Chem. 287, 12815-12827. doi: 10.1074/jbc.M112.340158

Halbach, A., Landgraf, C., Lorenzen, S., Rosenkranz, K., Volkmer-Engert, R., Erdmann, R., et al. (2006). Targeting of the tail-anchored peroxisomal membrane proteins PEX26 and PEX15 occurs through C-terminal PEX19-binding sites. J. Cell Sci. 119, 2508-2517. doi: 10.1242/jcs.02979

Hayashi, M., and Nishimura, M. (2006). Arabidopsis thaliana-a model organism to study plant peroxisomes. Biochim. Biophys. Acta 1763, 1382-1391. doi: 10.1016/j.bbamcr.2006.08.014

Hettema, E. H., Girzalsky, W., Van Den Berg, M., Erdmann, R., and Distel, B. (2000). Saccharomyces cerevisiae Pex $3 p$ and Pex19p are required for proper localization and stability of peroxisomal membrane proteins. EMBO J. 19, 223-233. doi: 10.1093/emboj/19.2.223

Hoepfner, D., Schildknegt, D., Braakman, I., Philippsen, P., and Tabak, H. F. (2005). Contribution of the endoplasmic reticulum to peroxisome formation. Cell 122, 85-95. doi: 10.1016/j.cell.2005.04.025

Honsho, M., Tamura, S., Shimozawa, N., Suzuki, Y., Kondo, N., and Fujiki, Y. (1998). Mutation in PEX16 is causal in the peroxisome-deficient Zellweger syndrome of complementation group D. Am. J. Hum. Genet. 63, 1622-1630. doi: $10.1086 / 302161$

Itoyama, A., Michiyuki, S., Honsho, M., Yamamoto, T., Moser, A., Yoshida, Y., et al. (2013). Mff functions with Pex11p $\beta$ and DLP1 in peroxisomal fission. Biol. Open 2, 998-1006. doi: 10.1242/bio.20135298

Ivashchenko, O., Van Veldhoven, P. P., Brees, C., Ho, Y. S., Terlecky, S. R., and Fransen, M. (2011). Intraperoxisomal redox balance in mammalian cells: oxidative stress and interorganellar cross-talk. Mol. Biol. Cell 22, 1440-1451. doi: 10.1091/mbc.E10-11-0919

Kammerer, S., Arnold, N., Gutensohn, W., Mewes, H.-W., Kunau, W.-H., Heofler, G., et al. (1997). Genomic organization and molecular characterization of a gene encoding HsPxF, a human peroxisomal farnesylated protein. Genomics 45, 200-210. doi: 10.1006/geno.1997.4914

Kammerer, S., Holzinger, A., Welsch, U., and Roscher, A. A. (1998). Cloning and characterization of the gene encoding the human peroxisomal assembly protein Pex3p. FEBS Lett. 429, 53-60. doi: 10.1016/S0014-5793(98)00557-2

Kim, P. K., Mullen, R. T., Schumann, U., and Lippincott-Schwartz, J. (2006). The origin and maintenance of mammalian peroxisomes involves a de novo PEX16-dependent pathway from the ER. J. Cell Biol. 173, 521-532. doi: $10.1083 /$ jcb. 200601036

Kobayashi, S., Tanaka, A., and Fujiki, Y. (2007). Fis1, DLP1, and Pex11p coordinately regulate peroxisome morphogenesis. Exp. Cell Res. 313, 1675-1686. doi: 10.1016/j.yexcr.2007.02.028

Koch, A., Thiemann, M., Grabenbauer, M., Yoon, Y., McNiven, M. A., and Schrader, M. (2003). Dynamin-like protein 1 is involved in peroxisomal fission. J. Biol. Chem. 278, 8597-8605. doi: 10.1074/jbc.M211761200

Koch, A., Yoon, Y., Bonekamp, N. A., McNiven, M. A., and Schrader, M. (2005). A role for Fis 1 in both mitochondrial and peroxisomal fission in mammalian cells. Mol. Biol. Cell 16, 5077-5086. doi: 10.1091/mbc.E05-02-0159

Koch, J., and Brocard, C. (2012). PEX11 proteins attract Mff and human Fis1 to coordinate peroxisomal fission. J. Cell Sci. 125, 3813-3826. doi: $10.1242 /$ jcs. 102178

Koch, J., Pranjic, K., Huber, A., Ellinger, A., Hartig, A., Kragler, F., et al. (2010). PEX11 family members are membrane elongation factors that coordinate peroxisome proliferation and maintenance. J. Cell Sci. 123, 3389-3400. doi: $10.1242 /$ jcs.064907

Kragt, A., Voorn-Brouwer, T., Van Den Berg, M., and Distel, B. (2005). Endoplasmic reticulum-directed Pex3p routes to peroxisomes and restores peroxisome formation in a Saccharomyces cerevisiae pex $3 \Delta$ strain. J. Biol. Chem. 280, 34350-34357. doi: 10.1074/jbc.M505432200
Kunau, W.-H. (1998). Peroxisome biogenesis from yeast to man. Curr. Opin. Microbiol. 1, 232-237. doi: 10.1016/S1369-5274(98)80016-7

Lam, S. K., Yoda, N., and Schekman, R. (2010). A vesicle carrier that mediates peroxisome protein traffic from the endoplasmic reticulum. Proc. Natl. Acad. Sci. U.S.A. 107, 21523-21528. doi: 10.1073/pnas.1013397107

Lazarow, P. B. (2003). Peroxisome biogenesis: advances and conundrums. Curr. Opin. Cell Biol. 15, 489-497. doi: 10.1016/S0955-0674(03)00082-6

Li, X., Baumgart, E., Dong, G.-X., Morrell, J. C., Jimenez-Sanchez, G., Valle, D., et al. (2002a). PEX11 $\alpha$ is required for peroxisome proliferation in response to 4 phenylbutyrate but is dispensable for peroxisome proliferator-activated receptor alpha-mediated peroxisome proliferation. Mol. Cell. Biol. 22, 8226-8240. doi: 10.1128/MCB.22.23.8226-8240.2002

Li, X., Baumgart, E., Morrell, J. C., Jimenez-Sanchez, G., Valle, D., and Gould, S. J. (2002b). PEX11 $\beta$ deficiency is lethal and impairs neuronal migration but does not abrogate peroxisome function. Mol. Cell. Biol. 22, 4358-4365. doi: 10.1128/MCB.22.12.4358-4365.2002

Li, X., and Gould, S. J. (2003). The dynamin-like GTPase DLP1 is essential for peroxisome division and is recruited to peroxisomes in part by PEX11. J. Biol. Chem. 278, 17012-17020. doi: 10.1074/jbc.M212031200

Liu, H., Tan, X., Veenhuis, M., McCullum, D., and Cregg, J. M. (1992). An efficient screen for peroxisome-deficient mutants of Pichia pastoris. J. Bacteriol. $174,4943-4951$.

Ma, C., Agrawal, G., and Subramani, S. (2011). Peroxisome assembly: matrix and membrane protein biogenesis. J. Cell Biol. 193, 7-16. doi: $10.1083 /$ jcb. 201010022

Ma, C., Hagstrom, D., Polley, S. G., and Subramani, S. (2013). Redox-regulated cargo binding and release by the peroxisomal targeting signal receptor, Pex5. J. Biol. Chem. 288, 27220-27231. doi: 10.1074/jbc.M113.492694

Matsumoto, N., Tamura, S., Moser, A., Moser, H. W., Braverman, N., Suzuki, Y., et al. (2001). The peroxin Pex6p gene is impaired in peroxisome biogenesis disorders of complementation group 6. J. Hum. Genet. 46, 273-277. doi: $10.1007 / \mathrm{s} 100380170078$

Matsuzaki, T., and Fujiki, Y. (2008). The peroxisomal membrane-protein import receptor Pex3 $p$ is directly transported to peroxisomes by a novel Pex19p- and Pex16p-dependent pathway. J. Cell Biol. 183, 1275-1286. doi: $10.1083 /$ jcb. 200806062

Matsuzono, Y., Kinoshita, N., Tamura, S., Shimozawa, N., Hamasaki, M., Ghaedi, K., et al. (1999). Human PEX19: cDNA cloning by functional complementation, mutation analysis in a patient with Zellweger syndrome and potential role in peroxisomal membrane assembly. Proc. Natl. Acad. Sci. U.S.A. 96, 2116-2121. doi: 10.1073/pnas.96.5.2116

Matsuzono, Y., Matsuzaki, T., and Fujiki, Y. (2006). Functional domain mapping of peroxin Pex19p: interaction with Pex3p is essential for function and translocation. J. Cell Sci. 119, 3539-3550. doi: 10.1242/jcs.03100

Miyata, N., and Fujiki, Y. (2005). Shuttling mechanism of peroxisome targeting signal type 1 receptor Pex5: ATP-independent import and ATP-dependent export. Mol. Cell. Biol. 25, 10822-10832. doi: 10.1128/MCB.25.24.10822-108 32.2005

Miyata, N., Hosoi, K., Mukai, S., and Fujiki, Y. (2009). In vitro import of peroxisome-targeting signal 2 (PTS2) receptor Pex7p into peroxisomes. Biochim. Biophys. Acta 1793, 860-870. doi: 10.1016/j.bbamcr.2009. 02.007

Miyata, N., Okumoto, K., Mukai, S., Noguchi, M., and Fujiki, Y. (2012). AWP1/ZFAND6 functions in Pex5 export by interacting with Cysmonoubiquitinated Pex5 and Pex6 AAA ATPase. Traffic 13, 168-183. doi: 10.1111/j.1600-0854.2011.01298.x

Motley, A. M., and Hettema, E. H. (2007). Yeast peroxisomes multiply by growth and division. J. Cell Biol. 178, 399-410. doi: 10.1083/jcb.200702167

Muntau, A. C., Mayerhofer, P. U., Paton, B. C., Kammerer, S., and Roscher, A. A. (2000). Defective peroxisome membrane synthesis due to mutations in human PEX3 causes Zellweger syndrome, complementation group G. Am. J. Hum. Genet. 67, 967-975. doi: 10.1086/303071

Nair, D. M., Purdue, P. E., and Lazarow, P. B. (2004). Pex7p translocates in and out of peroxisomes in Saccharomyces cerevisiae. J. Cell Biol. 167, 599-604. doi: 10.1083/jcb.200407119

Nuttley, W. M., Brade, A. M., Gaillardin, C., Eitzen, G. A., Glover, J. R., Aitchison, J. D., et al. (1993). Rapid identification and characterization of peroxisomal assembly mutants in Yarrowia lipolytica. Yeast 9, 507-517. doi: $10.1002 /$ yea.320090506 
Okumoto, K., Misono, S., Miyata, N., Matsumoto, Y., Mukai, S., and Fujiki, Y. (2011). Cysteine ubiquitination of PTS1 receptor Pex5p regulates Pex5p recycling. Traffic 12, 1067-1083. doi: 10.1111/j.1600-0854.2011.01217.x

Otera, H., Setoguchi, K., Hamasaki, M., Kumashiro, T., Shimizu, N., and Fujiki, Y. (2002). Peroxisomal targeting signal receptor Pex5p interacts with cargoes and import machinery components in a spatiotemporally differentiated manner: conserved Pex5p WXXXF/Y motifs are critical for matrix protein import. Mol. Cell. Biol. 22, 1639-1655. doi: 10.1128/MCB.22.6.1639-1655.2002

Otera, H., Wang, C., Cleland, M. M., Setoguchi, K., Yokota, S., Youle, R. J., et al. (2010). Mff is an essential factor for mitochondrial recruitment of Drpl during mitochondrial fission in mammalian cells. J. Cell Biol. 191, 1141-1158. doi: $10.1083 /$ jcb.201007152

Otzen, M., Perband, U., Wang, D., Baerends, R. J., Kunau, W. H., Veenhuis, M., et al. (2004). Hansenula polymorpha Pex19p is essential for the formation of functional peroxisomal membranes. J. Biol. Chem. 279, 19181-19190. doi: 10.1074/jbc.M314275200

Platta, H. W., Grunau, S., Rosenkranz, K., Girzalsky, W., and Erdmann, R. (2005). Functional role of the AAA peroxins in dislocation of the cycling PTS1 receptor back to the cytosol. Nat. Cell Biol. 7, 817-822. doi: 10.1038/ncb1281

Platta, H. W., Magraoui, F. E., Bäumer, B. E., Schlee, D., Girzalsky, W., and Erdmann, R. (2009). Pex2 and Pex12 function as protein-ubiquitin ligases in peroxisomal protein import. Mol. Cell. Biol. 29, 5505-5516. doi: 10.1128/MCB.00388-09

Sacksteder, K. A., Jones, J. M., South, S. T., Li, X., Liu, Y., and Gould, S. J. (2000). PEX19 binds multiple peroxisomal membrane proteins, is predominantly cytoplasmic, and is required for peroxisome membrane synthesis. J. Cell Biol. 148, 931-944. doi: 10.1083/jcb.148.5.931

Schatz, G., and Dobberstein, B. (1996). Common principles of protein translocation across membranes. Science 271, 1519-1526. doi: 10.1126/science.271.5255.1519

Schrader, M., Reuber, B. E., Morrell, J. C., Jimenez-Sanchez, G., Obie, C., Stroh, T. A., et al. (1998). Expression of PEX11 $\beta$ mediates peroxisome proliferation in the absence of extracellular stimuli. J. Biol. Chem. 273, 29607-29614. doi: 10.1074/jbc.273.45.29607

Schuldiner, M., Metz, J., Schmid, V., Denic, V., Rakwalska, M., Schmitt, H. D., et al. (2008). The GET complex mediates insertion of tail-anchored proteins into the ER membrane. Cell 134, 634-645. doi: 10.1016/j.cell.2008.06.025

Shimozawa, N., Nagase, T., Takemoto, Y., Suzuki, Y., Fujiki, Y., Wanders, R. J. A., et al. (2002). A novel aberrant splicing mutation of the PEX16 gene in two patients with Zellweger syndrome. Biochem. Biophys. Res. Commun. 292, 109-112. doi: 10.1006/bbrc.2002.6642

Shimozawa, N., Suzuki, Y., Zhang, Z., Imamura, A., Ghaedi, K., Fujiki, Y., et al. (2000). Identification of PEX3 as the gene mutated in a Zellweger syndrome patient lacking peroxisomal remnant structures. Hum. Mol. Genet. 9, 1995-1999. doi: 10.1093/hmg/9.13.1995

Shimozawa, N., Tsukamoto, T., Nagase, T., Takemoto, Y., Koyama, N., Suzuki, Y., et al. (2004). Identification of a new complementation group of the peroxisome biogenesis disorders and PEX14 as the mutated gene. Hum. Mutat. 23, 552-558. doi: 10.1002/humu.20032

Shimozawa, N., Tsukamoto, T., Suzuki, Y., Orii, T., Shirayoshi, Y., Mori, T., et al. (1992). A human gene responsible for Zellweger syndrome that affects peroxisome assembly. Science 255, 1132-1134. doi: 10.1126/science.1546315

South, S. T., and Gould, S. J. (1999). Peroxisome synthesis in the absence of preexisting peroxisomes. J. Cell Biol. 144, 255-266. doi: 10.1083/jcb.144.2.255

South, S. T., Sacksteder, K. A., Li, X., Liu, Y., and Gould, S. J. (2000). Inhibitors of COPI and COPII do not block PEX3-mediated peroxisome synthesis. J. Cell Biol. 149, 1345-1360. doi: 10.1083/jcb.149.7.1345

Subramani, S., Koller, A., and Snyder, W. B. (2000). Import of peroxisomal matrix and membrane proteins. Annu. Rev. Biochem. 69, 399-418. doi: 10.1146/annurev.biochem.69.1.399

Tabak, H. F., Braakman, I., and Distel, B. (1999). Peroxisomes: simple in function but complex in maintenance. Trends Cell Biol. 9, 447-453. doi: 10.1016/S09628924(99)01650-5
Tabak, H. F., Braakman, I., and Van Der Zand, A. (2013). Peroxisome formation and maintenance are dependent on the endoplasmic reticulum. Annu. Rev. Biochem. 82, 723-744. doi: 10.1146/annurev-biochem-081111125123

Tanaka, A., Kobayashi, S., and Fujiki, Y. (2006). Peroxisome division is impaired in a $\mathrm{CHO}$ cell mutant with an inactivating point-mutation in dynaminlike protein 1 gene. Exp. Cell Res. 312, 1671-1684. doi: 10.1016/j.yexcr.200 6.01 .028

Tanaka, A., Okumoto, K., and Fujiki, Y. (2003). cDNA cloning and characterization of the third isoform of human peroxin Pex11p. Biochem. Biophys. Res. Commun. 300, 819-823. doi: 10.1016/S0006-291X(02)02936-4

Titorenko, V. I., and Rachubinski, R. A. (2001). The life cycle of the peroxisome. Nat. Rev. Mol. Cell Biol. 2, 357-368. doi: 10.1038/35073063

Tsukamoto, T., Miura, S., and Fujiki, Y. (1991). Restoration by a $35 \mathrm{~K}$ membrane protein of peroxisome assembly in a peroxisome-deficient mammalian cell mutant. Nature 350, 77-81. doi: 10.1038/350077a0

Van Der Klei, I. J., and Veenhuis, M. (1996). Peroxisome biogenesis in the yeast Hansenula polymorpha: a structural and functional analysis. Ann. N. Y. Acad. Sci. 804, 47-59. doi: 10.1111/j.1749-6632.1996.tb18607.x

Van Der Zand, A., Braakman, I., and Tabak, H. F. (2010). Peroxisomal membrane proteins insert into the endoplasmic reticulum. Mol. Biol. Cell 21, 2057-2065. doi: 10.1091/mbc.E10-02-0082

Waterham, H. R., Koster, J., Van Roermund, C. W. T., Mooyer, P. A. W., Wanders, R. J. A., and Leonard, J.V. (2007). A lethal defect of mitochondrial and peroxisomal fission. N. Engl. J. Med. 356, 1736-1741. doi: 10.1056/NEJMoa064436

Weller, S., Gould, S. J., and Valle, D. (2003). Peroxisome biogenesis disorders. Annu. Rev. Genomics Hum. Genet. 4, 165-211. doi: 10.1146/annurev.genom.4.070802.110424

Wickner, W., and Schekman, R. (2005). Protein translocation across biological membranes. Science 310, 1452-1456. doi: 10.1126/science.1113752

Williams, C., Van Den Berg, M., Sprenger, R. R., and Distel, B. (2007). A conserved cysteine is essential for Pex4p-dependent ubiquitination of the peroxisomal import receptor Pex5p. J. Biol. Chem. 282, 22534-22543. doi: 10.1074/jbc.M702038200

Yagita, Y., Hiromasa, T., and Fujiki, Y. (2013). Tail-anchored PEX26 targets peroxisomes via a PEX19-dependent and TRC40-independent class I pathway. J. Cell Biol. 200, 651-666. doi: 10.1083/jcb.201211077

Yano, T., Oku, M., Akeyama, N., Itoyama, A., Yurimoto, H., Kuge, S., et al. (2010). A novel fluorescent sensor protein for visualization of redox states in the cytoplasm and in peroxisomes. Mol. Cell. Biol. 30, 3758-3766. doi: 10.1128/MCB.00121-10

Yonekawa, S., Furuno, A., Baba, T., Fujiki, Y., Ogasawara, Y., Yamamoto, A., et al. (2011). Sec16B is involved in the endoplasmic reticulum export of the peroxisomal membrane biogenesis factor peroxin 16 (Pex16) in mammalian cells. Proc. Natl. Acad. Sci. U.S.A. 108, 12746-12751. doi: 10.1073/pnas.11032 83108

Conflict of Interest Statement: The authors declare that the research was conducted in the absence of any commercial or financial relationships that could be construed as a potential conflict of interest.

Received: 10 June 2014; paper pending published: 26 June 2014; accepted: 28 July 2014; published online: 15 August 2014.

Citation: Fujiki Y, Okumoto K, Mukai S, Honsho M and Tamura S (2014) Peroxisome biogenesis in mammalian cells. Front. Physiol. 5:307. doi: 10.3389/fphys.2014.00307

This article was submitted to Integrative Physiology, a section of the journal Frontiers in Physiology.

Copyright (c) 2014 Fujiki, Okumoto, Mukai, Honsho and Tamura. This is an openaccess article distributed under the terms of the Creative Commons Attribution License (CC BY). The use, distribution or reproduction in other forums is permitted, provided the original author(s) or licensor are credited and that the original publication in this journal is cited, in accordance with accepted academic practice. No use, distribution or reproduction is permitted which does not comply with these terms. 